\title{
New Risks Ahead: \\ The Eastward Enlargement of the Eurozone
}

Michael Bolle, Christian Fahrholz, Hanns-D. Jacobsen, Thomas Meyer

Jean Monnet

Centre of

Excellence 


\title{
New Risks Ahead: The Eastward Enlargement of the Eurozone
}

\author{
Michael Bolle*, Christian Fahrholz, Hanns-D. Jacobsen, Thomas Meyer
}

\begin{abstract}
Eastward enlargement is one of the hot topics in European economics. The accession of central and eastern European Countries (CEEC) into the European Union (EU) is accompanied by an extension of the eurozone to this region. This paper surveys likely outcomes and challenges of this specific feature of EU enlargement. Moreover, the article represents the start of an intemational research project dealing with these questions.

Research is structured along different markets. Hence, the impact of an adoption of the euro is analysed for capital and labour markets as well as with respect to exchange rate and monetary policies. Our main position is that the euro has in general beneficiary effects for the CEEC and the current EU in all examined markets. However, these benefits evolve mainly in the long run, whereas the short-term costs of adaptation to the new situation may be high. Although we believe that the present value of long-term benefits exceeds these costs, it is by no means clear that policy-makers will share this view. Due to the usual political-economy transformation, the assessment of costs and benefits may be different for politicians than compared to any overall perspective. If official policies become unforeseeable, so will private behaviour. International investors may reverse their capital flows, draining precious liquidity, and leading to currency and financial crises whenever they perceive the authorities' commitment to EMU less credible.

This article highlights some thinkable mechanisms how any such crisis could evolve. It, thus, sets the agenda for further research, mainly, with the focus on appropriate policy strategies to keep adaptation costs as low as possible, minimise other external risks, without hampering the long-term benefits.
\end{abstract}

JEL-Classification: E0, E6, G 3

Keywords: EMU, EU enlargement, monetary integration

Corresponding author:

Prof. Dr. Michael Bolle

Freie Universität Berlin

Jean Monnet Centre of Excellence

Ihnestr. 22

D-14195 Berlin

Email: bosch2@zedat.fu-berlin.de

- Michael Bolle is a Professor of Political Science and Director of the Freie Universität Berlin's Jean Monnet Centre of Excet lence. He and his team coordinate the research program "EZONEPLUS - The Eastward Enlargement of the Eurozone", supported by the European Union. The project includes research institutions from Estonia, Finland, Italy, Poland, Portugal and Slovenia. 


\section{Introduction}

As it seems, the enlargement process of the European Union (EU) has become irreversible. Thus, three or four years down the road the first Central and East European Countries (CEEC) of the former socialist bloc will become members of the European Union. There can be no doubt that the accession process will shape policies and markets, of both current and prospective members. Additionally, expansion eastward will have numerous implications for the distribution of political and economic weight within the European Union. Adjustment to the new conditions will change the traditional flow of goods, services, capital and people and provide a new set of incentives for economic activity.

Eastward enlargement comes at a time when the eurozone struggles with the introduction of the euro. It can be argued that the European Monetary Union (EMU) is changing the character of the European Union in a fundamental way because the eurozone member countries (currently twelve out of fifteen EU members) have agreed to permanently abstain from rational economic policy instruments such as monetary and exchange rate policies and to accept the European Central Bank (ECB) as the decision making body to determine interest rates and money supply. It goes without saying that such an institution is not able to fine-tune its decisions in order to meet particular economic challenges in specific member countries. The existence of varying inflation rates in different member countries and the determination of one single interest rate by the ECB may create disruptive responses. In this respect, the eurozone is likely to be confronted with difficult adjustment processes in the future, the more so when recession ears will induce rational policy makers to guarantee their re- election by deliberately violating agreed-upon rules.

Once the accession of CEEC to the EU has begun, the eastward enlargement of the eurozone will be only a couple of more years away. After all, it has been one of the 1993 Copenhagen EU-accession criteria "to take on the obligations of membership, including (...) the Economic and Monetary Union (EMU)". In fact, some CEEC politicians and economists have even been toying with the idea of introducing the euro unilaterally because the stability criteria have been grossly met and because they want to speed up the accession process. Membership of accession countries in the elrozone, however, may cause additional risks both for the CEEC and for the EMU itself. First of all, these countries have to face all the consequences the current eurozone members already bear. But, in addition and in contrast to those already part of the EMU, applicants from the CEEC must cope with the fact that they have to continue their transformation efforts towards market economies and that their productivity and income will remain long-term way below the average level of the current eurozone, even below the position of countries such as Portugal and Greece which currently bring up the rear.

With this background, the objectives of this paper are to give an overview of how policies and markets are shaped by the prospective enlargement of the eurozone with the CEEC. It will be shown that their renunciation of monetary sovereignty will give the process of European integration a substantial new quality in risks. This contribution examines the prospective risks involved in two steps. In the first section, three different channels of risks will be discussed in order to sensitise for impacts of the prospective shaping of policies and mar- 
kets in the CEEC during their integration into the European Monetary Union. First, we discuss the challenges to eastern European capital markets in transition with regard to traderelated and FDI-issues, especially the need to finance economic development as reflected by increased current account deficits. Second, we analyse the consequences for labour markets and possible impacts for social and welfare regimes. Third, we look at risks that will be transmitted via monetary policies. Closely elated to the above-mentioned channels of risk, monetary and exchange rate policies will be of major interest (when capital mobility is high, exchange rate policy is essentially monetary policy). Due to the expected BalassaSamuelson-effect, causing real appreciation tendencies in the CEEC in the medium term, the renunciation of monetary sovereignty may trigger high costs, urging the CEEC to disinflate their economies. The last section, finally, indicates possible implications for risk assessment based on the conclusions of our analysis. Eventually, for instance, minimising risks could encompass a revision of the EMUcriteria laid out in the Maastricht treaty, in order to adequately cope with the special needs of CEEC.

\section{Capital markets and financial flows}

The financial landscape in applicant states will be most prominently affected by the euro. Capital markets in these countries have improved tremendously over the past decade. The 1999 transition indicators of the European Bank for Reconstruction and Development (EBRD) show good grades for the progressive applicant states on most financial issues. In fields such as banking reform, commercial law, and financial regulation these countries usually achieve grades above 3 on a scale from 1 to
4+) and consequently, these areas are not at the top of the agenda for further reform. ${ }^{1}$ However, the development level of mature economies is still far from being reached.

A second glance reveals fundamental problems. One crucial dimension for the functioning of capital markets is their institutional framework in which financial transactions are embedded. This framework is still in the process of being defined. ${ }^{2}$ It is important to note that the EBRD differentiates between extensiveness and effectiveness according to the respective indicators; extensiveness is usually ranked 0 to 3 notches higher than effectiveness, ${ }^{3}$ indicating that there is still room for institutional arbitrage. Moreover, there is considerable evidence that asymmetric information is an important shortcoming in most financial systems of EU applicants: Although interest rate spreads lie between 5.8 (Poland) and 3.1 (Hungary) percentage points, i.e., well below Germany's of 6.4 (but higher than the 2.7 spread in the US), domestic bank credit amounts to only 35 (Estonia) up to 63 (Czech Republic) percent of GDP, compared to 145 in Germany and even 164 in the US. ${ }^{4}$ Lower prices together with lower quantities traded can be interpreted here as credit rationing which is a standard reaction of business parties to markets with asymmetric information. ${ }^{5}$ This view is supported by the fact that barter and other non-monetary transactions are far from negligible even in the advanced transition countries. Between 11 (Hungary) and 86 percent (Slovenia) of firms engage more or less regularly in these trades, indicating that demand for financing exceeds supply. ${ }^{6}$

The apparent shortcomings in the accession states' financial sector, especially with regard to the institutional framework, have two major consequences: The arrival of the euro has the 
potential to precipitate capital market development, whereas on the other hand, this leap forward may easily fail and inflict tremendous cost on these countries.

A major source of risk is the dependency on capital inflows, which are needed to level with mature economies' capital endowment. Gross capital formation in the applicant states amounts to $25-29$ percent of GDP, which is higher than the usual low twenties figures of mature economies but less than the 30 percent prevalent in East Asia. ${ }^{7}$ The high investment quotas indicate a closing of the gap with Western countries, however, as they are largely financed by foreign capital inflows, they also represent considerable risk.

The 5 to 7 percent of GDP of net foreign capital inflows are fuelled by the expectation of improving economic and political conditions and are guaranteed by accession to the European Union, albeit xtual economic conditions might not justify them. Today, candidates benefit enormously from these net inflows for a number of reasons: (1) capital market development is precipitated because foreign actors appear, who are able and willing to take over important monitoring and governance functions, (2) capital endowment can be increased without stressing too much domestic savings quotas or the domestic financial system's ability to raise funds, (3) the accompanying current account deficit does not play a significant role, as overall cemand should not be a problem in a transition country with ts need to make up for the shortage in consumption, and (4) cause most of the capital inflows come in the form of foreign direct investments, not only financing is imported, but also foreign competence, know-how, and competition, which should improve product market's efficiency.
However, these capital inflows still come at a price.

Indeed, huge capital inflows spurred by the belief in a splendid economic future and a volatile financial world may resemble the advent of the East Asian turmoil four years ago. What, one may ask, will happen if expectations of future economic improvements are built on sand? Can East Asia be a blueprint for a worst-case scenario in Eastern Europe? In 1997, the sudden devaluation of the Thai baht led to an unexpected, though not unprecedented, reversal of capital flows in a magnitude, which has brought down the whole region. What if markets lose faith in a quick accession of applicant countries to the eurozone, or even to the EU? Missing the 2004 deadline of the Gothenburg summit could be a plausible trigger. What if entering the eurozone does not yield the benefits hoped for? It may kecome clear that merely overtaking of the euro does not promote good governance to the expected extent, and thus, market imperfection will persist with investments becoming less attractive. What happens once the trigger is pulled is well known from previous crises: The loss of capital inflows threaten to imbalance the balance of payments, and hence, demands depreciation of the local currency in order $b$ reduce trade deficits. The depreciation, however, devalues asset prices such as equity shares. Even if depreciation can be fought off, rising interest rates would harm assets to a similar extent. Investors will try to avoid losses in their stakes and withdraw further funds from that currency thereby precipitating the downward spiral of depreciation. What else happens cepends on local circumstances. If large amounts of credit are denominated in foreign currency a financial and banking crisis will be likely. ${ }^{8}$ Anyway, as investors will be satisfied on a first-come, first- 
served basis, such a crisis resembles the standard multiple equilibria model. ${ }^{9}$ The only necessary condition for a crisis to happen is when the country or region is in a zone of general vulnerability.

Prospective members of the eurozone will enter at least one dangerous transition period: the time between EU accession and admittance to the eurozone. Then, early benefits will be expected and initial disappointments may appear. Moreover, any delay in enlarging the eurozone will then become obvious and may trigger the crisis. Even if a reversal of financial flows does not immediately lead to crisis, applicant states would forgo benefits (1), (2), and (4). Moreover, the then rising need to reduce the trade deficit will most likely result in a reduction of overall demand and thus harm economic growth.

\section{Labour markets and the social dimension}

Whatever affects employment and social well being must be of special interest to policymakers because it influences their chances of re-election. Unemployment rates in the progressive applicant states are between 4.7 (Czech Republic) and 10.5 (Poland) percent. These rates are still too high, with the probable exception of the Czech Republic; however, compared to western European standards they do not seem excessive. Moreover, social $\infty$ hesion seems not to be endangered as is shown with indicators such as the Ginicoefficient, which has values of 24 (Hungary) up to 38 (Estonia). In most accession countries Gini-coefficients are around the 30 of Germany and none exceed the 40 of the US. ${ }^{10}$ Thus, unequal income distribution does not seem to be a likely source of social conflict in the near future.

However, the devil lies in the detail. Athough unemployment rates might not be excessive, the high ratio of long-term unemployment (between 30 and 51 percent of total unemployment) is disturbing. This high share indicates rigid labour markets, which may be the consequence of the communist employment system, but constitutes the potential for future problems. Accession to the eurozone will lead to the constraint of domestic economic policy. Neither fiscal nor monetary policies will have the potential to accommodate real economic shocks, which raises the usual concerns in regard to optimum currency areas. CEEC production structure differs widely from those of existing EU-members in many respects: lower capital endowment, lower productivity, higher share of agricultural production, etc. Due to these differences, applicant states are much likelier to be subject to adverse asymmetric shocks, and because of the little economic weight these countries will have in euroland, the chance is less that the European Central Bank might comfort such shocks by relaxing monetary policy. Other remedies are migration, which obviously will not be tolerated especially by neighbouring countries such as Austria or Germany, and deregulation of labour markets.

Market participants will adapt to changing market conditions, as long as these alterations are credible. The constraints enforced by the euro, i.e., criteria of Maastricht and the Stability Pact, are much more precise than the mere obligation to sound economic policies demanded by the acquis communautaire. Moreover, old members of the EU might accept deviation from the consensus of good economic policies in the then new member states as long as they do not belong to the eurozone, for political reasons or in order to allow for a short-term facilitation of the still ongoing transition process. As soon as the euro will be adopted by selected CEEC, old members will be much 
less likely to tolerate unsound economics because they would affect their own welfare through at least two channels: (1) Expansionary fiscal and monetary policies would increase inflationary pressures which have to be borne by all euroland members via rising interest rates. Note, that the magnitude of this channel is rather limited due to the small economic weight the CEEC will have within euroland. (2) Allowing any new member to violate oriteria of Maastricht or Stability Pact could serve as bad example for others and will thus be avoided. Hence, with the arrival of the euro, economic constraints for applicant CEEC must be presumed to be much more binding.

Boundaries in economic discretion will shape labour markets by changing the behaviour of relevant actors. First of all, there are the contract partners, unions and business associations, which determine wages and labour conditions. With no accommodating monetary or fiscal policy in sight, it will be more and more necessary to resist the urge for higher wages and premium conditions. This is a learning process that is already visible, for instance, in the moderate wage increases in current eurozone members.

More flexible labour markets are beneficiary for long-term economic performance. In the short term they may be costly in economic and plitical terms, which is even reinforced by the special circumstances of transition. A likely scenario is that high skilled labour in modern, export-orientated sectors of the economy will benefit from more flexible labour markets in the form of higher wages and improved working conditions, whereas the rest of the workforce will suffer from deteriorating circumstances. Such wage differentials are aggravated in the CEEC because of the high share of employment in agriculture and the public sector, which are characterised by low productivity, and hence, will only experience mediocre development. The same holds for the large part of publicly controlled and owned enterprises, which, as a consequence of the socialist legacy, exhibit a too high employment per output and only few growth options. The aforementioned large share of long-term unemployment shows the difficulty of integrating workers from communist-style firms into modern employment. Outsiders of the prospering parts of the economy do also include people who have retreated from the labour market, such as pensioners.

Thus, liberalisation of labour markets will induce an insider-outsider problem, where insiders may reap most of the benefits and outsider bear most of the social costs. Improved welfare throughout the population and a vanishing border between insiders and outsiders is only possible in the long run.

CEEC governments are then between a rock and a hard place. Deregulation of labour markets will lead to social costs and might, endanger re-election, especially as outsiders like pensioners and public employees traditionally exhibit a very strong political lobby. With fewer economic tools at their disposal, adverse economic shocks can only be absorbed via flexible labour markets or will lead to unemployment and a shrinking economy. Although it seems quite obvious that the first option is favourable, because of its positive long-term perspective, it is by no means clear that this option will be chosen in the CEEC. The reason is that those who suffer from a shrinking economy in the second case may be politically less influential and are thus easier to discriminate against. 


\section{Monetary and exchange-rate policies}

The way in which monetary and respectively exchange rate policies are affected by the prospective accession of the CEEC to EMU, is connected with the appearance of the socalled Balassa-Samuelson-effect. The expected phenomenon is, first of all, elated to the economies of the CEEC. This is however likewise generating a qualitative risk amongst current members of EMU. That risk, being a negative externality of the economic performances of the CEEC, may enhance co-operative European efforts to internalise expected negative consequences of a Balassa-Samuelsoneffect.

The possibility of increasing productivity and growth rates in the CEEC due to the prospective accession to the EMU may create additional inflationary pressures. The expected leaps in productivity are due to the liberalisation of markets, international trading and intensified competition. Moreover, the productivity rates are expected to accelerate within the CEEC more quickly than outside, i.e. within the current members of the EMU, due to the intensifying competition. That effect is accompanied as has been shown above by a positive impact of net capital inflows on quotas of FDI. However, increased productivity refers mainly to the sector of tradable goods. With the higher productivity comes increasing income levels, i.e. increasing rates of wages. The rising level of wages, however, is not exclusively restricted to the sector of tradable goods: The price level in the sector of non-tradable goods will increase too. Because of lacking progress in productivity in that sector the higher costs on the supply-side, that is the wages, are passed on to the consumer-prices. While the inflation rates of the CEEC in the sector of tradable goods adapt to the respective level in the cur- rent EU due to competition, it is not necessarily valid for the development of the price level within the sector of non-tradable goods. Thereby, a mark-up in prices for non-tradable goods and non-substitutable services in CEEC contributes to an increase in the average price level. This is essentially the BalassaSamuelson-effect, which may cause several severe problems for the monetary policies in the CEEC.

The accession candidates will at least have to choose their exchange rate regimes twice on their path toward the EMU. One of the Maastricht criteria for monetary convergence is the participation in the successor of the European Exchange Rate Mechanism (ERM2), in the last two years without realignment. ${ }^{11}$ Members of ERM2 may determine the fluctuation band from a maximum size of $+/-15$ percent to zero percent as long as monetary conditions are perceived to cope with these targets. The former choice of an appropriate exchange rate regime before entering ERM2 is the more $n$ teresting case regarding the BalassaSamuelson-effect. Such an exchange-rate regime has to meet at least two obligations: First, net capital inflows should be stabilised and international competition should not be worsened. Second, the exchange-rate regime has to cope with internal policy objectives (for instance employment), too. However, because of the Balassa-Samuelson-effect, i.e. the rise of the average price level, the currencies of the CEEC tend toward a real appreciation in the medium term, which will worse their ability to compete. Moreover, transition economies have a higher potential for quality improvements than mature markets. Corresponding higher prices are hard to tell apart from nominal increases, thus, the measured average inflation rates may be higher for statistical reasons. ${ }^{12}$ 
Therefore, the CEEC are being urged to disinflate their economies in order to cope with their exchange-rate obligations.

Accordingly, restricted monetary sovereignty and the given exchange rate requirements may trigger high costs The costs of an ongoing disinflation, caused for instance by rising unemployment rates, may exceed the advantages of fixed exchange-rates. As a consequence such parity may be suspended. Even with a most sensibly chosen exchange-rate regime a government and respectively central bank may be forced to give up if market sentiments turn against them. That is when internal and external objectives are considered to be too much conflicting. Consequently, there are some distortions in the fundamentals and a reversal of capital-flows in the corresponding economy. With these consequences directly affecting a country, such a change in the monetary policy and the abandonment of the exchange-rate regime has further impacts on the economic performances of other CEEC and current members of the EMU as well. The other CEEC might be affected by trade/ financial linkages and externalities due to asymmetric information: If market sentiments consider all CEEC as one type of economy, the failure of one country's exchange-rate regime will give a "bad signal", forcing other countries to adjust monetary and respectively exchange-rate policy. That line of argument emphasises the possible impact on the current members of EMU as well. Eventually, it can be assessed that such a negative policy externality of a single country's performance is generating a systemic risk, i.e. disrupting the economic and political performances of all European countries.

However, with regard to the impact on the current EMU by the prospective membership of the CEEC, another agument has to be put in place. Since transparency in the decisionmaking process of the European Central Bank (ECB) is lacking, the ECB could be expected to concern itself with the economic performances of the CEEC. Markets could expect the monetary policy of the ECB to be more relaxed than normally necessary in order to achieve price stability - for instance, to improve the ability of the CEEC to atract capital inflows by lowering its interest rates. Accordingly, the risk-premia for EMU would rise and the ECB would actually have to raise interest rates. All current members of the EMU would be worse off.

\section{Conclusions}

The analyses of the previous sections have shown that considerable risk lies ahead on the road toward the EMU. Even small changes in expectations, can lead to severe economic drawbacks. Eventually, this could trigger a financial crisis àla Southeast Asia 1997.

Moreover, accession to the EMU will mpose numerous constraints on the economic policies of candidates and, thereby, enforce market adjustment. In the end, these adjustments are expected to reshape CEEC markets for the good, however, there is still the possibility that policy-makers will not allow appropriate market adjustment in order to maintain their political support. The cost would have to be borne by those less organised and less able to deal with conflict. The overall economic performance would be hampered. Finally, the transition to the currency regime, monetary union, exhibits in itself considerable costs and risks. The CEEC, are still transition countries and suffer from real sector inefficiencies (e.g. BalassaSamuelson), which are likely to lead to real appreciation of domestic currencies or render 
disinflation unnecessarily expense for rather technical reasons.

Risks and costs will not be limited to the CEEC but will also have repercussions on current EMU-members. Hence, it has been argued that Maastricht criteria should be supplemented by further real convergence indicators, taking into account real sector problems. Two directions can be distinguished: (1) Those who emphasise costs and risks for the current EMU-members argue in favour of a criterion that requires far-leading real economic convergence, for instance with respect to incomelevels, and hence make accession to the EMU harder; ${ }^{13}$ (2) those who emphasise adjustment costs for the CEEC argue in favour of a relaxation of Maastricht criteria in order to facilitate accession.

Both arguments are flawed because neither take into account the political cost. Although an additional indicator for real convergence might make economic sense, actually choosing one is far from trivial. Any country not being permitted access to the EMU, based on this indicator, might perceive it to be a political, not economic, instrument to justify its exclusion. The same holds true for any criterion designed to loosen the convergence burden for the CEEC. Any deviation from Maastricht-criteria could then be excused by the legacy of transition or by other Balassa-Samuelson-like factors, giving the possibility to allow accession cespite the violation of Maastricht and without losing face. Hence, the urge for good economic policies would be reduced because adapting the indicator instead of reforming policies would be an easier way out. The roots of the impracticality of any real convergence criterion thus lie in the absence of any convincing concept of design. Although attempts have been made in the past, cf. the OCA-indicator of Eichengreen and Bayoumi $^{14}$ or the convergence indicator of Deutsche Bank Research, ${ }^{15}$ no consensus exists in detail on how such an indicator should be created. Therefore, any chosen indicator would immediately be subjected to reflecting political bargaining rather than to economic reasoning.

Accession to the EMU offers tremendous chances for the most progressive CEEC, which can be felt even now. A glance at monetary figures reveals the latest progress - sinking inflation, converging interest rates, and improving financial market conditions - which is at least partly due to generally positive expectations. However, the ongoing path may prove to be too thorny with numerous roadblocks ahead. Some of those have been described in this paper, but a great deal of them has not been considered yet. 


\section{Notes}

${ }^{1}$ International Monetary Fund: World Economic Outlook, Washington D.C., 2000; European Bank for Reconstruction and Development: Transition Report, London, 2000.

${ }^{2}$ M. Aoki: Controlling Insider Control: Issues of Corporate Governance in Transition Economies, in: Masahiko Aoki, Hyung-Ki Kim (eds.): Corporate Governance in Transitional Economies: Insider Control and the Role of Banks, EDI Development Study, Washington, 1995

${ }^{3}$ EBRD 2000

${ }^{4}$ World Bank, World Development Indicators (WDI), Washington D.C., 2001.

5 cf. J. Stiglitz, A. Weiss: Credit Rationing in Markets with Imperfect Information, in: American Ec onomic Review, Vol. 71, 1981, pp. $393-411$.

${ }^{6}$ W. Carlin, S. Fries, M. Schaffer, P. Seabright: Barter and Non-Monetary Transactions in Transition Economies: Evidence from a Cross-Country Survey, CERT Discussion Paper, No. 4, 2000.

${ }^{7} \mathrm{WDI}$

${ }^{8}$ F. Mishkin: International Capital Movements, Financial Volatility and Financial Stability, in: Finanzmärkte im Spannungsfeld von Globalisierung, Regulierung und Geldpolitik, Schriften des Vereins für Socialpolitik, Band 261, 1998, pp. 11-40.

${ }^{9}$ S. Radelet, J. Sachs: What Have We Learned, So Far, From The Asian Financial Crisis?, 1999.

(http://www.hiid.havard.edu/pub/other/aea122.pdf)

${ }_{10}$ WDI

${ }^{11}$ The concept of ERM2 may become obsolete if, for instance, the United Kingdom would be allowed to join EMU without a twoyear-membership. For reasons of equal treatment it would then be hard to refuse accession of any other country.

${ }^{2}$ Besides inflationary bias in CEEC on account of the Balassa-Samuelson-effect and the above mentioned statistical reasons, there is another channel for inflation: Nominal inertia can be expected to continue as price liberalisation in these transformation countries has not been completed yet. In the meantime, until enhanced competition will reduce price dynamics, higher inflation will be the consequence.

${ }^{13} \mathrm{H}$. Siebert: Die EU-Osterweiterung erfordert ein neues Konvergenzkriterium, in: Handelsblatt, 22.02.2001, p. 14.

${ }^{14} \mathrm{~T}$. Bayoumi, B. Eichengreen: Ever closer to heaven? An optimum currency area index for European countries, in: European Economic Review, Vol. 41, 1997, pp. 761-770.

${ }^{15}$ Deutsche Bank Research: EU Enlargement Monitor no. 1, Frankfurt a.M., September 2000. 